$\begin{array}{cc}\text { ACADEMIA ROMÂNĂ } & \text { Rev. Roum. Chim., } \\ \text { 2019, 64(8), 673-679 }\end{array}$

\title{
EVALUATION OF CHEMICAL CONTENT AND RADICAL SCAVENGING ACTIVITY OF ALLIUM VINEALE L. EXTRACT AND ITS ELEMENTAL ANALYSIS
}

\author{
İbrahim TEGIN, ${ }^{\mathrm{a}^{*}}$ Erdal YABALAK, ${ }^{\mathrm{b}}$ Betül SADIK ${ }^{\mathrm{a}}$ and Mehmet FIDAN ${ }^{\mathrm{c}}$ \\ ${ }^{a}$ Siirt University, Faculty of Arts and Science, Department of Chemistry, Siirt- TR-56100, Turkey \\ ${ }^{b}$ Mersin University, Faculty of Arts and Science, Department of Chemistry, Mersin TR-33343, Turkey \\ ${ }^{\mathrm{c}}$ Siirt University, Faculty of Arts and Science, Department of Biology, Siirt- TR-56100, Turkey
}

Received September 25, 2018

Allium vineale L. was extensively analysed to determine its radical scavenging activity, chemical composition, total polyphenol content, and elemental composition. The Soxhlet and the subcritical water extraction methods were performed for the extraction procedure. The extracts obtained in the subcritical water extraction method were evaluated by GC-MS. 11 compounds were determined according to mass spectral libraries of GC-MS, Wiley7Nist05.L, NIST05a.L, W9N11.L. The

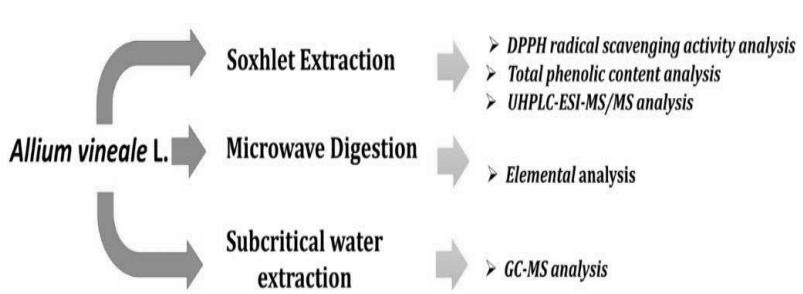
obtained compounds were evaluated for their benefits on health according to literature. DPPH inhibition of Allium vineale L. was obtained as $58.60 \%$ and the total polyphenol content of Allium vineale $\mathrm{L}$. was obtained as $12 \mu \mathrm{g} / \mathrm{mL}$ gallic acid equivalent. 28 elements were obtained in the elemental analysis by ICP-MS, using the microwave digestion procedure. UHPLC-ESI-MS/MS analysis was performed for the evaluation of methanolic extract of Allium vineale L. obtained in the Soxhlet extraction method.

\section{INTRODUCTION}

Allium species (Liliaceous) have been widely used for alternative medicine almost all over the world since ancient times. ${ }^{1-5}$ Investigations have shown that Allium species are beneficial and may be effective in preventing cardiovascular diseases, tumour promotion, and ageing. ${ }^{2-5}$ Several Allium species of both cultivated species and wild species from various locations have been evaluated to enlighten their antioxidative potentials by researchers. ${ }^{6}$ Besides, antioxidative properties ${ }^{7,8}$ of leaves of various wild and grown Allium sorts were examined for their activities of antioxidant enzymes (superoxide dismutase, catalase, peroxidase, and glutathione peroxidase), hydroxyl radicals and reduced glutathione, and quantities of malonyldialdehyde superoxide. ${ }^{9}$
The antibacterial activity of Allium vineale L. (A. vineale) was studied and was found to be at a quite high level. ${ }^{10}$ In addition, organic solvent extracts (methanolic and ethanolic extracts, etc.) of this plant can be used as natural antibacterial additives for the incorporation in cheese and various food products. ${ }^{10}$

Allium genus is a natural food and consumed by many communities. There are 198 natural taxa belonging to the genus Allium in Turkey. A. vineale grows in Siirt, Van and Hakkari provinces in Turkey and it is regionally called Sirık or Sirma. $A$. vineale have been used for herbed cheese production in Turkey for many centuries. ${ }^{10}$ It is consumed by citizens because it gives a nice taste and a pleasant smell when mixed with cheese. ${ }^{11,12}$

In the present study, the subcritical water extraction (SWE) method was performed to

\footnotetext{
*Corresponding author: ibrahim.tegin@gmail.com
} 
determine the chemical content of $A$. vineale. SWE is carried out under the temperature conditions between $100-374{ }^{\circ} \mathrm{C}$ and under sufficient pressure conditions to keep the water in the liquid phase. ${ }^{13}$ SWE method has advantages of being environmentally friendly, very cheap, easy to find, not toxic and it does not leave organic waste. ${ }^{13}$ Total phenolic contents of $A$. vineale and DPPH radical scavenging activity were spectrophotometrically determined. The presence of several phenolic acids in the A. vineale was determined using UHPLC analysis. Phenolic contents and fatty acid compositions were determined by LC-MS/MS and GC-MS. ${ }^{14-16}$ ICP-MS, which is a type of mass spectroscopy and is highly sensitive and allows the determination of metals and several non-metals at a concentration level of $\mathrm{ppb}$, was used for elemental determinations. ${ }^{17}$

\section{MATERIAL AND METHOD}

\section{Chemicals and Instruments}

The Soxhlet apparatus was used to extract $A$. vineale and the rotary evaporator (Hei-VAP, Heidolph Instruments, Germany) was used to concentrate the extract samples. Phenolic content compositions were determined by LC-MS/MS (Shimadzu, Kyoto, Japan). ${ }^{16}$ The Berghof Speedwawe MWS-3 model microwave was used in the digestion process of $A$. vineale. The Thermo Scientific brand I CAP Q model ICP-MS instrument was used for the metal analysis of the plant. $\mathrm{HNO}_{3}$ and $\mathrm{H}_{2} \mathrm{O}_{2}, 2$,2-diphenyl-1-picrylhydrazyl (DPPH•), Folin-Ciocalteau's phenol reagent, gallic acid, $\mathrm{C}_{7}-\mathrm{C}_{40}$ saturated alkane standard mixture and ascorbic acid were obtained from Sigma Sigma-Aldrich (St. Louis, MO). All other reagents were of analytical grade. The UV mini-1240 spectrophotometer (Shimadzu, Duisburg, Germany) was used to measure the total phenolic content and the radical scavenging activity (DPPH). SWE experiments were done using a stainless steel cylindrical extractor $(100 \mathrm{~mm} \times 5 \mathrm{~mm}$ i.d.). Both ends of the extractor were covered with $0.45 \mu \mathrm{m}$ mesh size filters to prevent the particulates. The experimental set-up as shown in previous work was used for SWE extraction experiments. ${ }^{18}$ The Soxhlet apparatus was used in the Soxhlet extraction process.

\section{Plant material}

The plant of $A$. vineale was collected in Eruh district of Siirt of south eastern Anatolia region of
Turkey province in April 2015 and identified by Dr Mehmet Fidan. This specimen has been stored at the Herbarium of Siirt University (Herbarium plant number: MeF 2427). The collected plant samples were dried, powdered and then stored in a jar for further analysis.

\section{The procedure \\ of the subcritical water extraction method}

In the other part of this study, samples to be extracted were prepared by adding the mixture of $0.5 \mathrm{~g}$ dried and powdered $A$. Vineale sample and $0.5 \mathrm{~g}$ of sea sand into the extraction cell. The extraction cell was covered by glass wool, screwed on, placed into the oven and pressurized with water. After static mode extraction $(30 \mathrm{~min})$, the exit valve was opened and the extracts were collected in ultra-pure water during dynamic mode extraction. $5 \mathrm{~mL}$ of water was used in SWE for each experiment. SWE experiments were performed at $105^{\circ} \mathrm{C}$ under 40 bar of $\mathrm{N}_{2}$ gas in the constant pressure mode. The solvent of the obtained extract was evaporated by the rotary evaporator and residue was dissolved in methanol.

\section{GC-MS Analysis}

The methanolic extract of $A$. vineale was analysed by GC-MS to identify its chemical composition. GC-MS was operated by the method given in the previous work ${ }^{18}$. A certified reference material, $\mathrm{C}_{7}-\mathrm{C}_{40}$ saturated alkane mixture, which contains each $\mathrm{C}_{7}-\mathrm{C}_{40}$ component in a concentration of $1000 \mu \mathrm{g}$ in $\mathrm{mL}$ of hexane was used to determine the Kováts index of identified compounds.

\section{The procedure of the Soxhlet extraction method}

Samples of $A$. vineale were subjected to the Soxhlet extraction method for analysis of phenolic compounds by LC-MS/MS. $10 \mathrm{~g}$ of dried and powdered plant sample was subjected to a Soxhlet extraction system containing $160 \mathrm{~mL}$ of 80:20 methanol-water mixture as a solvent. LC-MS/MS was operated using the method given by Ertaş et $a l$. to determine phenolic content composition. ${ }^{16}$

\section{Extract Preparation of A. vineale for total phenolic compounds and DPPH radical scavenging activity analysis}

A mixture of $10 \mathrm{~g}$ of dried and powdered A. vineale sample and $100 \mathrm{~mL}$ of the methanol- 
water mixture $(80: 20 \%)$ was shaken at $37{ }^{\circ} \mathrm{C}$ for 24 hours. Next, the mixture was filtered through rough filter paper into a glass container. Then, Methanol was removed by a rotary evaporator and the amount of residue was determined. After that, the concentration of each plant sample was dissolved again with methanol to adjust the concentration to be $10 \mathrm{mg} / \mathrm{mL}$. Finally, the samples were kept in the refrigerator for further analyses.

\section{Total phenolic content analysis}

The total phenolic contents of plant materials were determined using the Folin-Ciocalteau's as a reagent and gallic acid as standard. This method relies on the reaction of phenolic contents with the Folin-Ciocalteau's reagent and phenolic contents were determined by measuring the blue colour of the formed compound in the visible section of the spectrum ${ }^{19}$. An aliquot $(0.2 \mathrm{~mL})$ of extracts and Folin-Ciocalteau's reagent $(1 \mathrm{~mL})$ were added to a volumetric flask. After incubation for $6 \mathrm{~min}$ at room temperature, $1 \mathrm{~mL}$ of $7 \% \mathrm{Na}_{2} \mathrm{CO}_{3}$ solution was added and the mixture was shaken. The absorbance of the mixed solution was measured at $760 \mathrm{~nm}$ with a UV mini-1240 Spectrophotometer. The same procedure was repeated with gallic acid solutions $(8-200 \mathrm{mg} / \mathrm{mL})$. All samples were analysed in 3 replicates. The amount of the total phenolic content was calculated using a standard curve $\left(\mathrm{R}^{2}=0.9994\right)$ of gallic acid constituted by using the concentration of each gallic acid solution $(0-0.2 \mathrm{mg} / \mathrm{mL})$ against its absorbance.

\section{DPPH analysis}

The DPPH assay was performed according to the method explained by Villaño et al. ${ }^{20}$ Briefly, a solution of $0.5 \mathrm{~mL}$ of sample and $2 \mathrm{~mL}$ of 0.01 $\mathrm{mM}$ DPPH (dissolved in methanol) were stirred and incubated for $30 \mathrm{~min}$ in dark. The absorbance of the mixture was measured at $517 \mathrm{~nm}$ with a UV mini-1240 Spectrophotometer. The percentage inhibition was calculated by the formula given below.

$$
\text { Inhibition } \%=\left(\frac{A_{c}-A_{i}}{A_{c}} \times 100\right)
$$

where $A_{c}$ is the control absorbance and $A_{i}$ is the absorbance values of the sample.

\section{Microwave Digestion Process of A. vineale}

The digestion process of the plant sample was performed by the Berghof Speedwawe MWS-3 model microwave digestion apparatus under the operating conditions given in Table 1. In this process, $0.5 \mathrm{~g}$ part of the dried plant was weighed and put into the pressure-resistant PTFE (Polytetrafluoroethylene) vessel. 10:2 $\mathrm{mL}$ of $\mathrm{HNO}_{3}: \mathrm{H}_{2} \mathrm{O}_{2}$ acid mixture was added to the plant sample. The digestion process was operated under conditions given in Table 1.

\section{RESULTS AND DISCUSSION}

\section{The chemical composition \\ of A. vineale extracts obtained by SWE}

SWE of A. vineale plant was performed under optimum conditions. Extracts were collected after a specific time under $105{ }^{\circ} \mathrm{C}$ and 40 bar. To determine extracted compounds, samples were analysed by GC-MS according to Wiley7Nist05.L, NIST05a.L, W9N11.L. The determined compounds are given in Table 2. Though characteristics of these compounds vary on a wide range, they may show antioxidative activity one by one or collectively. Some of the compounds given in Table 2 were evaluated below according to literature. Krist et al. enlightened the volatile compounds of a series poppy seed oil. Ethanoic acid, which was found in our study (component number of 1 in Table 2), is one of the obtained compounds in their work with retention index of $660 .{ }^{21}$ Also, Pino et al. identified ethanoic acid as a component of Morinda citrifolia $\mathrm{L}^{22}$ Aly et al. determined 3-amino-2-ethylbutanoic acid study (component number of 6 in Table 2) in the GC-MS analysis of ethyl acetate fraction extracted from Dalbergia Sissoo. ${ }^{23}$ According to the work done by Mochizuki et al., in which Allium sativum L. was comprehensively analysed, it was found that Allium sativum L. has antibacterial activity, antifungal activity, virucidal activity, etc. due to containing active sulfur compounds. ${ }^{24}$ Herein, we determined dimethyl trisulfide (component number of 7 in Table 2) as a sulphurous compound of $A$. vineale. 2,3-Dihydro-3,5-dihydroxy-6-methyl-4Hpyran-4-one (component number of 8 in Table 2) was found as one of the components of ether extract of Panax ginseng, which was proposed for 
its antifungal and antitumor properties by $\mathrm{Xu}$ et $a l .{ }^{25} \mathrm{p}$-vinylguaiacol (2-methoxy-4-vinylphenol) (component number of 9 in Table 2) was detected by Asuming et al. In the investigation of the essential oil composition of four Lomatium Raf. Species. ${ }^{26}$ The retention index, found for this compound by Asuming et al., is quite close to our findings.

\section{Total phenolic content analysis}

The total phenolic amount was found as a result of the method applied to the extract obtained from $A$. vineale, as indicated in literature, ${ }^{12}$ and the obtained values are given in Table 3. Besides, the amount of antioxidant was analysed as given in literature $^{13}$ and the obtained result is given in Table 3.

\section{Quantitative analysis of phenolic compounds}

As indicated in literature ${ }^{27,28}$ the UHPLC-ESIMS/MS technique is used in the quantitative analysis of phenolic compounds. An accurate quantitative method was developed on a mass spectrometer equipped with a triple quadrupole analyser for the analyses of twenty-seven compounds. $^{14-16}$ The methanol extracts of $A$. vineale were analysed to quantify these compounds by the mentioned method. The obtained results are given in Table 4.

Table 1

Operating conditions of the digestion process

\begin{tabular}{lll}
\hline & $\mathbf{1}$ & $\mathbf{2}$ \\
\hline $\mathrm{T}\left({ }^{\circ} \mathrm{C}\right)$ & 150 & 190 \\
$\mathrm{P}$ bar & 50 & 50 \\
$\mathrm{Ta}(\min )^{\mathrm{a}}$ & 70 & 90 \\
${\text { Time }(\min )^{\mathrm{b}}}^{\mathrm{b}}$ & 5 & 5 \\
\hline
\end{tabular}

${ }^{a}$ Waiting time at the desired temperature; ${ }^{b}$ Time between the two sequential temperatures.

Table 2

GC-MS results of extracts obtained from SWE of $A$. vineale

\begin{tabular}{|c|c|c|c|c|c|c|c|c|c|}
\hline $\begin{array}{l}\text { C. } \\
\text { No }\end{array}$ & $\begin{array}{l}\mathrm{RT} \\
(\mathrm{min})\end{array}$ & $\begin{array}{l}\text { Peak } \\
\text { Area } \\
(\%)\end{array}$ & Compound Name & $\begin{array}{l}\text { Chemical } \\
\text { Formula }\end{array}$ & $\begin{array}{l}\text { Molecular } \\
\text { weight } \\
(\mathrm{g} / \mathrm{mol})\end{array}$ & $\begin{array}{l}\text { Peak } \\
\text { Quality } \\
(\%)\end{array}$ & KI & RIL & $\begin{array}{l}\text { Ref } \\
\text { No. }\end{array}$ \\
\hline 1 & 2.92 & 10.27 & Ethanoic acid & $\mathrm{C}_{2} \mathrm{H}_{4} \mathrm{O}_{2}$ & 60.05 & 86 & $\overline{\mathrm{nc}}$ & 660 & 19 \\
\hline 2 & 3.26 & 3.14 & Glycidyl alcohol & $\mathrm{C}_{3} \mathrm{H}_{6} \mathrm{O}_{2}$ & 74.08 & 58 & $\mathrm{nc}$ & nd & nd \\
\hline 3 & 3.56 & 1.75 & Glyoxalic acid & $\mathrm{C}_{2} \mathrm{H}_{2} \mathrm{O}_{3}$ & 74.04 & 59 & $\mathrm{nc}$ & nd & nd \\
\hline 4 & 4.64 & 1.41 & Cyclobutanol & $\mathrm{C}_{4} \mathrm{H}_{8} \mathrm{O}$ & 72.11 & 53 & $\mathrm{nc}$ & nd & nd \\
\hline 5 & 5.96 & 1.41 & Cyclopropyl carbinol & $\mathrm{C}_{4} \mathrm{H}_{8} \mathrm{O}$ & 72.11 & 51 & $\mathrm{nc}$ & nd & nd \\
\hline 6 & 7.59 & 4.32 & 3-amino-2-ethylbutanoic acid & $\mathrm{C}_{6} \mathrm{H}_{13} \mathrm{NO}_{2}$ & 131.09 & 60 & $\mathrm{nc}$ & nd & nd \\
\hline 7 & 8.46 & 3.10 & Dimethyl trisulfide & $\mathrm{C}_{2} \mathrm{H}_{6} \mathrm{~S}_{3}$ & 126.26 & 91 & 975.64 & 972 & 20 \\
\hline 8 & 14.19 & 9.27 & $\begin{array}{l}\text { 2,3-Dihydro-3,5-dihydroxy-6- } \\
\text { methyl-4H-pyran-4-one }\end{array}$ & $\mathrm{C}_{6} \mathrm{H}_{8} \mathrm{O}_{4}$ & 144.13 & 68 & 1160.48 & 1162 & 21 \\
\hline 9 & 21.93 & 9.67 & p-Vinylguaiacol & $\mathrm{C}_{9} \mathrm{H}_{10} \mathrm{O}_{2}$ & 150.07 & 94 & 1318.65 & 1315 & 22 \\
\hline 10 & 22.74 & 1.54 & Myocol & $\mathrm{C}_{10} \mathrm{H}_{13} \mathrm{~N}_{5} \mathrm{O}_{4}$ & 267.24 & 53 & 1353.66 & nd & nd \\
\hline 11 & 69.94 & 0.74 & Gibberellic acid & $\mathrm{C}_{19} \mathrm{H}_{22} \mathrm{O}_{6}$ & 346.37 & 55 & 3263.07 & nd & nd \\
\hline
\end{tabular}

RT: Retention times, C. No: Component number, KI: Kovats index, RIL: Retention Index obtained from literature, nc: not calculated, nd: not detected

Table 3

The total phenolic content and DPPH radical scavenging activity of $A$. vineale

\begin{tabular}{ccc}
\hline Sample (Locality) & \%DPPH Inhibi tion & $\begin{array}{c}\text { Gallic acid equivalent } \boldsymbol{\mu g} / \mathbf{m L} \\
\text { (Total phenolic) }\end{array}$ \\
\hline A. vineale (Siirt-Eruh/Turkey) & 58.60 & 12.00 \\
\hline
\end{tabular}


Table 4

Compounds of the methanolic extract of $A$. vineale

\begin{tabular}{llcc}
\hline C. No & Compound & ( $\mu$ a analyte/kg extract) & SD \% \\
\hline 1 & Hesperidin & nd & nd \\
2 & Coumarin & nd & nd \\
3 & Quinic acid & 14796.17 & 710.22 \\
4 & Malic acid & 29904.61 & 1435.42 \\
5 & tr-Aconitic acid & 11.4 & 0.55 \\
6 & Gallic acid & nd & nd \\
7 & Chlorogenic acid & 5.01 & 0.24 \\
8 & Protocatechuic acid & 7.03 & 0.34 \\
9 & Tannic acid & 219.76 & 10.55 \\
10 & tr-caffeic acid & 5.19 & 0.25 \\
11 & Vanillin & 4.32 & 0.21 \\
12 & Rosmarinic acid & nd & nd \\
13 & p-Coumaric acid & 179.56 & 8.62 \\
14 & Rutin & 0.81 & 0.04 \\
15 & Hyperoside & 213.83 & 10.26 \\
16 & Myricetin & nd & nd \\
17 & Fisetin & nd & nd \\
18 & 4-OH Benzoic acid & nd & nd \\
19 & Salicylic acid & nd & nd. \\
20 & Quercetin & 9.62 & 0.46 \\
21 & Kaempferol & 41.79 & 2.01 \\
22 & Naringenin & nd & nd \\
23 & Hesperetin & nd & nd \\
24 & Luteolin & 24.44 & 1.17 \\
25 & Apigenin & 61.03 & 2.93 \\
26 & Rhamnetin & 249.85 & 11.99 \\
27 & Chysin & nd & nd \\
\hline
\end{tabular}

nd: not detected.

Table 5

Elemental analyses of $A$. vineale

\begin{tabular}{c|c|c|c|c|c|c|c}
\hline $\mathbf{L i}(\mathrm{ppb})$ & $\mathbf{B e}(\mathrm{ppb})$ & $\mathbf{C o}(\mathrm{ppb})$ & $\mathbf{A s}(\mathrm{ppb})$ & $\mathbf{S e}(\mathrm{ppb})$ & \multicolumn{1}{c|}{$\mathbf{C d}(\mathrm{ppb})$} & $\mathbf{S b}(\mathrm{ppb})$ \\
\hline $242.85 \pm 2.215$ & $3.42 \pm 0.27$ & $132.48 \pm 1.23$ & $26.37 \pm 1.32$ & \multicolumn{1}{c}{$93.28 \pm 8.31$} & \multicolumn{2}{|c}{$5.76 \pm 2.49$} & $4.24 \pm 0.02$ \\
\hline $\mathbf{L a}(\mathrm{ppb})$ & $\mathbf{C e}(\mathrm{ppb}$ & $\mathbf{T l}(\mathrm{ppb})$ & $\mathbf{P b}(\mathrm{ppb})$ & $\mathbf{V}(\mathrm{ppb})$ & \multicolumn{2}{|c}{$\mathbf{Z n}(\mathrm{ppm}$} & $\mathbf{M n}(\mathrm{ppm}$ \\
\hline $62.82 \pm 0.23$ & $85.18 \pm 1.21$ & $2.69 \pm 0.11$ & $180.32 \pm 0.71$ & $191.35 \pm 3.57$ & \multicolumn{2}{c}{$7.75 \pm 0.04$} & $10.46 \pm 0.12$ \\
\hline $\mathbf{S r}(\mathrm{ppm})$ & $\mathbf{M o}(\mathrm{ppm})$ & $\mathbf{F e}(\mathrm{ppm})$ & $\mathbf{S n}(\mathrm{ppm})$ & $\mathbf{C u}(\mathrm{ppm})$ & $\mathbf{B a}(\mathrm{ppm})$ & $\mathbf{N a}(\mathrm{ppm})$ \\
\hline $6.51 \pm 0.10$ & $0.80 \pm 0.03$ & $75.50 \pm 1.41$ & $3.53 \pm 0.31$ & $4.27 \pm 0.08$ & \multicolumn{2}{c}{$4.84 \pm 0.07$} & $291.20 \pm 2.38$ \\
\hline $\mathbf{B}(\mathrm{ppm})$ & $\mathbf{M g}(\mathrm{ppm})$ & $\mathbf{P}(\mathrm{ppm})$ & $\mathbf{K}(\mathrm{ppm})$ & $\mathbf{T i}(\mathrm{ppm})$ & $\mathbf{C a}(\mathrm{ppm})$ & $\mathbf{C r}(\mathrm{ppm})$ \\
\hline $10.99 \pm 0.08$ & $745.80 \pm 13.33$ & $1020.24 \pm 11.30$ & $1425.31 \pm 4.95$ & $3.78 \pm 0.20$ & $2046.87 \pm 8.98$ & $0.94 \pm 0.03$ \\
\hline
\end{tabular}

The chromatogram of standard mix and chromatogram of $A$. Vineale methanol extracts as shown in Fig. 1 and Table 4, quinic and malic acids were found to be the most abundant compounds, (14.79 and $29.90 \mathrm{mg} / \mathrm{g}$ extract, respectively) in the methanol extracts of $A$. vineale. Furthermore, traconitic acid, chlorogenic acid, protocatechuic acid, tannic acid, tr-caffeic acid, vanillin, p-coumaric acid, rutin, hyperoside, quercetin, kaempferol, luteolin, apigenin, and rhamnetin were also detected in the methanol extract of this plant (Table 4).
Additionally, hesperidin, coumarin, gallic acid, rosmarinic acid, myricetin, fisetin, 4-OH benzoic acid, salicylic acid, quercetin, naringenin, hesperetin, and chysin were not identified in the methanol extract of $A$. vineale.

\section{Elemental analysis of $A$. vineale}

The elemental analysis of $A$. Vineale plant was performed using ICP-MS and the obtained results were given in Table 5 . 

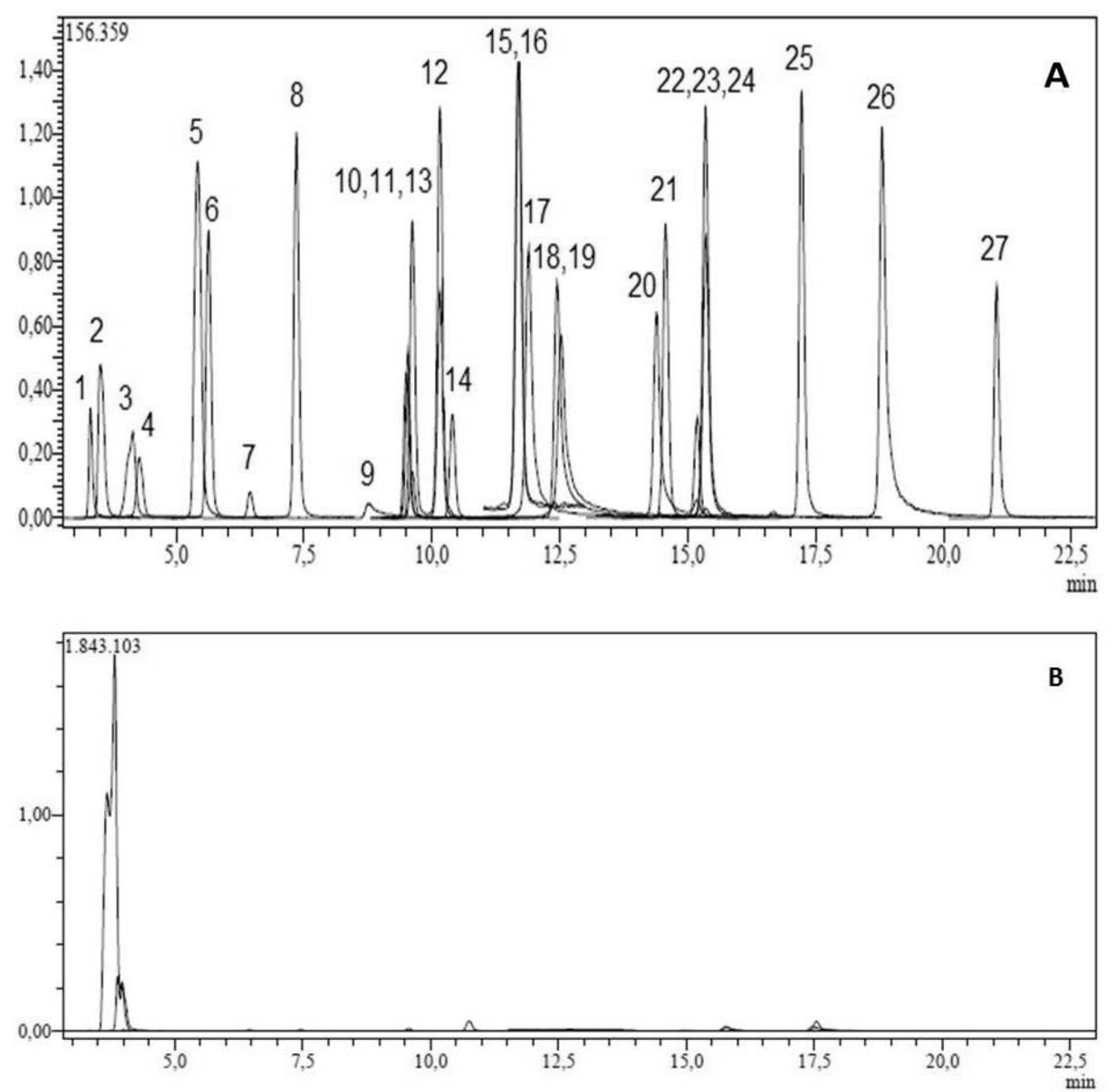

Fig. 1. A - UHPLC-ESI-MS/MS chromatogram of standard mix (1: quinic acid, 2: malic acid, 3: tr-aconitic acid, 4: gallic acid, 5: chlorogenic acid, 6: protocatechuic acid, 7: tannic acid, 8: tr- caffeicacid, 9: vanillin, 10: p-coumaric acid, 11: rosmarinic acid, 12: rutin, 13: hesperidin, 14: hyperoside, 15: 4-OH benzoic acid, 16: salicylic acid, 17: myricetin, 18: fisetin, 19: coumarin, 20: quercetin, 21: naringenin, 22: hesperetin, 23: luteolin, 24: kaempferol, 25: apigenin, 26: rhamnetin, 27: chrysin). B: UHPLC-ESI-MS/MS chromatogram of Allium Vineale L. methanol extract.

When Table 5 is examined, it is seen that the values of $\mathrm{P}, \mathrm{Fe}, \mathrm{Na}, \mathrm{Mg}$, and $\mathrm{K}$ are very high in $\mathrm{mg} / \mathrm{g}$ level. While Ti, Cr, Mn, $\mathrm{Cu}$; $\mathrm{Zn}, \mathrm{Sr}, \mathrm{Mo}, \mathrm{Sn}$, and $\mathrm{Ba}$ element values were found to be in the range of 1-10 ppm, element values of $\mathrm{Li}, \mathrm{Be}, \mathrm{V}$, $\mathrm{Se}, \mathrm{Cd}, \mathrm{Sb}, \mathrm{La}, \mathrm{Ce}, \mathrm{Tl}$ and $\mathrm{Pb}$ were determined at ppb level. While $\mathrm{Cr}$ and $\mathrm{Fe}$ values are parallel to the metal values in different vegetable and spice plants in literature ${ }^{29-31}, \mathrm{Co}, \mathrm{Mn}, \mathrm{Zn}, \mathrm{Cu}$ and $\mathrm{Sr}$ values are found to be lower. ${ }^{30}$

\section{CONCLUSIONS}

A. vineale plant, presented in this study, was collected from the rural district of Eruh in Siirt. In this study, the components of $A$. vineale were determined using the subcritical extraction method. Besides, the total phenolic amount, antioxidant capacity, phenolic compounds and metal values of the plant were studied. According to this study, quinic and malic acids (14.79 and $29.90 \mathrm{mg} / \mathrm{g}$ 
extract, respectively) were the most abundant phenolic compounds in $A$. vineale extracts. The total phenolic content and the DPPH radical scavenging activity of $A$. vineale were found as $58.60 \%$ and $12.00 \mu \mathrm{g} / \mathrm{mL}$, respectively. The values of $\mathrm{P}, \mathrm{Fe}, \mathrm{Na}, \mathrm{K}$, and $\mathrm{Mg}$ were found to be the highest in the elemental analysis of Allium $A$. vineale using ICP-MS. However, $\mathrm{Li}, \mathrm{Be}, \mathrm{V}, \mathrm{Co}$, $\mathrm{Ni}, \mathrm{As}, \mathrm{Se}, \mathrm{Sb}, \mathrm{La}, \mathrm{Ce}$ and $\mathrm{Pb}$ values were found to be very low at the ppb level.

Acknowledgements. This study was supported by the Research Fund of Siirt University in Turkey with Project Number: 2015-SIUFEB-33. This academic work was linguistically supported by the Mersin Technology Transfer Office Academic Writing Centre of Mersin University.

\section{REFERENCES}

1. E. Block, Sci. Am., 1985, 252, 114-118.

2. G. R. Fenwick, A. B. Hanley and J. R. Whitaker, $C R C$ Crit. Rev. Food Sci. Nutr., 1985, 22, 199-271.

3. G. R. Fenwick and A. B. Hanley, CRC Crit. Rev. Food Sci. Nutr., 1985, 22, 273-377.

4. G. R. Fenwick and A. B. Hanley, CRC Crit. Rev. Food Sci. Nutr., 1985, 23, 1-73.

5. H. Najjaa, E. Ammar and M. Neffati, J. Food Agric. Environ., 2009, 7, 150-154.

6. D. Štajner, N. Milić, J. Čanadanović-Brunet, A. Kapor, M. Štajner, and B. M. Popović, Phyther. Res., 2006, 20, 581-584.

7. I. Demirtas, R. Erenler, M. Elmastas and A. Goktasoglu, Food Chem., 2013, 136, 34-40.

8. D. Štajner, R. Igić, B. M. Popović and D. Malenčić, Phyther. Res., 2008, 22, 113-117.

9. D. Stajner and I. Szöllosi Varga, Acta Biol. Szeged., 2003, 47, 103-106.

10. H. Durmaz, E. Sagun, Z. Tarakci and F. Ozgokce, African J. Biotechnol., 2006, 5, 1795-1798.

11. A. Gencay, "Etnobotanical Aspects of Cizre (Şırnak)", Yüzüncü Y1l University Institute of Science and Technology, M.Sc. Thesis, 2007.
12. İ. Kaval, "Etnobotanical Features of Geçitli (Hakkari) and Surroundings", Yüzüncü Y1l University Institute of Science and Technology, M.Sc. Thesis, 2011.

13. E. Yabalak and A. M. Gizir, J. Serb. Chem. Soc., 2013, 78, 1013-1022.

14. A. Ertaş, M. Boğa, M. A. Yılmaz, Y.Yeşil, N.Haşimi, M. Ş. Kaya, H. Temel, U Kolak, J. Agric. Food Chem., 2014, 62, 4601-9.

15. A. Ertas, M. Boğa, M. A. Yılmaz, Y.Yeşil, G. Tel, H. Temel, N. Haşimi, I: Gazioglu, M. Ozturk, P. Ugurlu, Ind. Crops Prod., 2015, 67, 336-345.

16. A. Ertas, M. A. Yılmaz, M. Boğa, N. Haşimi, Y.Yeşil, A.C. Goren, H. Temel, G. Topcu, Int. J. Food Prop., 2016, 19, 124-138.

17. M. Batsala, B. Chandu, B. Sakala, S. Nama, S. Nama, D. Bosco, P. G. College, M. Vatticherukuru, A. Pradesh, Int. J. Res. Pharm. Chem., 2012, 2, 671-680.

18. E. Yabalak, Journal of the Turkish Chemical Society Section A: Chemistry, 2018, 5, 205-218.

19. K. Slinkard and V. Singleton, Am. J. Enol. Vitic., 1977, 28, 49-55.

20. D. Villaño, M. S. M. S. Fernández-Pachón, M. L. M. L., Moyá, A. M. A. M. Troncoso and M. C. C. M. C. GarcíaParrilla, Talanta, 2007, 71, 230-235.

21. S. Krist, G. Stuebiger, H. Unterweger, F. Bandion and G. Buchbauer, J. Agric. Food Chem., 2005, 53, 8310-8316.

22. J. A. Pino, E. Márquez, C. E., Quijano and D. Castro, Ciência e Tecnol. Aliment., 2010, 30, 183-187.

23. H. I. M. Aly, A. B. El-sayed, Y. M. Gohar and M. Z. M. Salem, Journal of Forest Products \& Industries, 2013, 2, 34-41.

24. E. Mochizuki, T. Yamamoto, Y. Komiyama and H. Nakazawa, J. Agric. Food Chem., 1998, 46, 5170-5176.

25. L. L. Xu, T. Han, J. Z. Wu, Q. Y. Zhang, H. Zhang, B. K. Huang, K. R., L. P. Qin, Phytomedicine, 2009, 16, 609-616.

26. W. A. Asuming, S. B. Philip, T. D. Josette, C. D. Barbara, D. Vasu, F. Scott, W. M. Catherine, Biochem. Syst. Ecol., 2005, 33, 17-26.

27. C. W. Lin, C. W. Yu, S. C. Wu and K. H. Yih, J. Food Drug Anal., 2009, 31, 475-476

28. S. C. Liu, T. L. Jau, C. H. Chao, Y. S. Bo, Y. C. Ting, L. C. Ya, H. S. Chia, J. Y. Deng, Food Chem., 2017, 215 , 284-291.

29. C. Karadaş and D. Kara, Food Chem., 2012, 130, 196-202.

30. D. Kara, Food Chem., 2009, 114, 347-354.

31. Ş. Tokalığlu, Food Chem., 2012, 134, 2504-2508. 
